\title{
EVALUATION OF THE NURSING CARE MODEL FOR CHILDREN VICTIMIZED OF VIOLENCE ${ }^{1}$
}

\author{
Patrícia Kuerten Rocha², Marta Lenise do Prado3 , Sherrill Conroy4, Denise Maria Guerreiro Vieira da Silva
}

${ }^{1}$ This study is a part of the doctoral thesis - Construction and validation of instrument for assessing models of nursing care developed in the Post-graduation Nursing Program, at the Federal University of Santa Catarina (UFSC), Brazil, in collaboration with the Nursing Faculty, University of Alberta, Edmonton, Canada, developed during March 2006 to September 2008.

${ }^{2} \mathrm{PhD}$ in Nursing. Professor of Department of Nursing at UFSC. Santa Catarina, Brasil. E-mail: patriciarocha@ccs.ufsc.br

${ }^{3}$ PhD in Nursing. Professor of Nursing Department of the Post-graduate Program in Nursing at UFSC. Researcher CNPq. Santa Catarina, Brasil. E-mail: mpradop@ccs.ufsc.br

${ }^{4} \mathrm{PhD}$. Professor of the Nursing Faculty of the University of Alberta. Canada. E-mail: sherrill.conroy@ualberta.ca

${ }^{5} \mathrm{PhD}$ in Nursing. Professor of the Nursing Department and the Post-graduate Program in Nursing at UFSC. CNPq Fellow. Santa Catarina, Brasil. E-mail: denise@ccs.ufsc.br

\begin{abstract}
The nursing care model represent important possibilities to develop the knowledge of nursing. However, there is no proposition that allow to verify the legitimacy of the care models. So, the objective of this study was to evaluate the Nursing Care Model for Children Victimized of Violence. The model was elaborated from a study of qualitative approach, the Convergent Assistant type. The study consists of evaluative study utilizing the instrument for evaluation of nursing care models, and conducted by a panel of 18 specialists. The analysis includes analysis of objective responses and other texts prepared by experts as part of its assessment process. The result shows that the Nursing Care Model, still needs tweaking and adaptations.
\end{abstract}

DESCRIPTORS: Nursing. Violence. Child. Child care.

\section{AVALIAÇÃO DE UM MODELO DE CUIDADO DE ENFERMAGEM PARA CRIANÇAS VÍTIMAS DE VIOLÊNCIA}

RESUMO: Modelos de cuidado de Enfermagem representam importante possibilidade de desenvolvimento do conhecimento de Enfermagem. Todavia, não há uma proposição que permita verificar a legitimidade dos modelos de cuidado. Assim, o objetivo deste estudo foi avaliar o Modelo de Cuidado de Enfermagem para Crianças Vítimas de Violência. O modelo foi elaborado a partir de uma pesquisa de abordagem qualitativa, do tipo Convergente-assistencial. O presente estudo consistiu em uma pesquisa avaliativa utilizando o instrumento para avaliação de modelos de cuidado de enfermagem, e efetuada por um painel de 18 especialistas. A análise abrange análise das respostas objetivas e dos textos elaborados pelas especialistas como parte do processo de avaliação que efetuaram. Os resultados evidenciaram que o Modelo de Cuidado para Crianças Vítimas de Violência, pode ser considerado um modelo de cuidado para a enfermagem, embora ainda necessite de ajustes e adequações.

DESCRITORES: Enfermagem. Violência. Criança. Cuidado da criança.

\section{EVALUACIÓN DE UN MODELO DE CUIDADO DE ENFERMERÍA A NIÑOS VÍCTIMAS DE LA VIOLENCIA}

\begin{abstract}
RESUMEN: Los modelos de cuidado de enfermería representan una importante oportunidad para desarrollar el conocimiento de enfermería. Sin embargo, aún no existe una proposición que permita verificar la legitimidad de esos modelos. El objetivo de este estudio fue evaluar el Modelo de Cuidado de Enfermería a Niños Víctimas de la Violencia. El modelo se hizo a partir de una investigación cualitativa, convergente asistencial. En este estudio se realiza una investigación evaluativa mediante el instrumento de evaluación de modelos de cuidado de enfermería, analizada por un panel de 18 especialistas. El análisis incluye el análisis de respuestas objetivas y otros textos elaborados por expertos como parte del proceso de evaluación que realizaron. Los resultados mostraron que el Modelo de Cuidado a Niños Víctimas de la Violencia, puede considerarse como un modelo para el cuidado de enfermería, pero aún necesita retoques y ajustes.
\end{abstract}

DESCRIPTORES: Enfermería. Violencia. Niño. Cuidado del niño 


\section{INTRODUCTION}

During the development process of nursing knowledge there have been proposed methods for systematization of care of the discipline. These proposals were aimed at developing systematic ways to care for the client/ family in order to allow the monitoring and evaluation of nursing.

Among these modes, there is the model of care, which receives different denominations such as the conceptual model, theory, methodology, models of nursing "frameworks" these are different terminologies used by different authors and are often interrelated when discussing the structure of nursing Knowledge. ${ }^{1}$

The nursing Knowledge are classified and structured in decreasing order of abstraction, may be defined in: metaparadigm, philosophy, conceptual models, theories and empirical indicators. $^{2}$ This structure of knowledge does not refer to the care model. To the author, the theories were derived from conceptual models that represents global vision of study reason (concepts and propositions) and utilizing blueprints for the application in the practice, in the education and in the study. ${ }^{3}$ The theories can be classified according to their degree of abstraction in large and medium. ${ }^{1-2}$

Models of care can be understood as a structure of nursing knowledge formed by a frame of reference (or theoretical mark) that defines the theoretical references and philosophical model as a methodology that describes the method of how care will be performed in practice. ${ }^{4}$

In Brazil in the mid eighties, different proposals of care models appeared, ${ }^{5-8}$ which has been progressively developed. Same ones that have not always been designated by their authors represent an important possibility for the development of nursing knowledge.

However, there is no proposition which verifies the legitimacy of the care models and its contribution to effective quality nursing care. From this, it is indispensible to verify how these models can be evaluated. To this end, we consider that care models are structures of knowledge that reach the subjectivity of care, while they can express their objective. Thus, the evaluation of the care model approaches the fundamentals that sustain the evaluation of qualitative research. Qualitative studies are difficult to be evaluated due to their features, and one of their main principal is to translate and express the meaning of the phenomenon of interest to the researcher, which is necessary, for both, use patterns and techniques, such as logic, the qualitative evaluation and common sense. ${ }^{9-10}$

The terms of reliability and validity are important to the qualitative study and they must not be checked only after finishing the study, because the researchers run the risks of committing damage in the reliability and validity of the proposed study. They indicate the use of strategies of verification like: the methodological coherence (congruence between the question of study and methods), the appropriate sample (evidence of the adequacy by saturation and replication), collection and analysis of data simultaneously by thinking theoretical (of data and ideas from being confirmed by new data) and theoretical development (as a result of the study process). ${ }^{11}$

Together, all these strategies are to enhance verification and interactively contribute to construction of reliability and validity that ensures accuracy. The accuracy of qualitative surveys can be questioned, challenged, and provide scientific pragmatic evidence. What must be integrated into the developed knowledge. ${ }^{11-12}$

Thus, authors stress the need to follow the rigor of the scientific study in their methodological proposals, but moreover, we perceive that we can develop methods to evaluate these studies, as instruments for appraisal. ${ }^{11}$

We believe that a nursing care model needs to be evaluated, a model which meets specific criteria covering all dimensions that it has. Thus the objective of this study was to evaluate the Nursing Care Model for Children Victimized of Violence using a proposed tool for evaluating nursing care models. ${ }^{13}$

\section{THE NURSING CARE MODEL FOR CHILDREN VICTIMIZED OF VIOLENCE}

The model of nursing care ${ }^{14}$ was elaborated from a study that was compiled from a survey of qualitative approach, the Convergent Assistance type, during the Master Course, between March of 2004 to August 2005, at the Federal University of Santa Catarina, Brazil.

The mark reference model ${ }^{14}$ was based on several authors and in our experience, beliefs and values of the author. It consists of four concepts (victimized children of violence, nursing care to children victimized of violence, therapeutic toys and institutionalization), along with principles.

The methodology of care based on the technique of the use of therapeutic dramatic toys or cathartic ${ }^{15}$; it describes in three steps how to use 
the therapeutic toys ${ }^{16}$ the principles of the nature of care $^{17}$ is based on mark reference that guided the study.

The methodology was articulated into steps, which compliment, and which occurs simultaneously or not. These steps were denominated as: "Welcoming (first step of this model of care, consisting of the first sessions of therapeutic play, the purpose is to establish a connection between the child and the nurse/researcher), Playing (second step, the nurse will use more expressive principles of care) and Finishing (last step, we check if the deficits were provided or if it is necessary to send the child to another professional)"14 which are directly related to the context and can be composed of one or more sessions of therapeutic toys.

For this model see the following graphic representation (Figure 1).

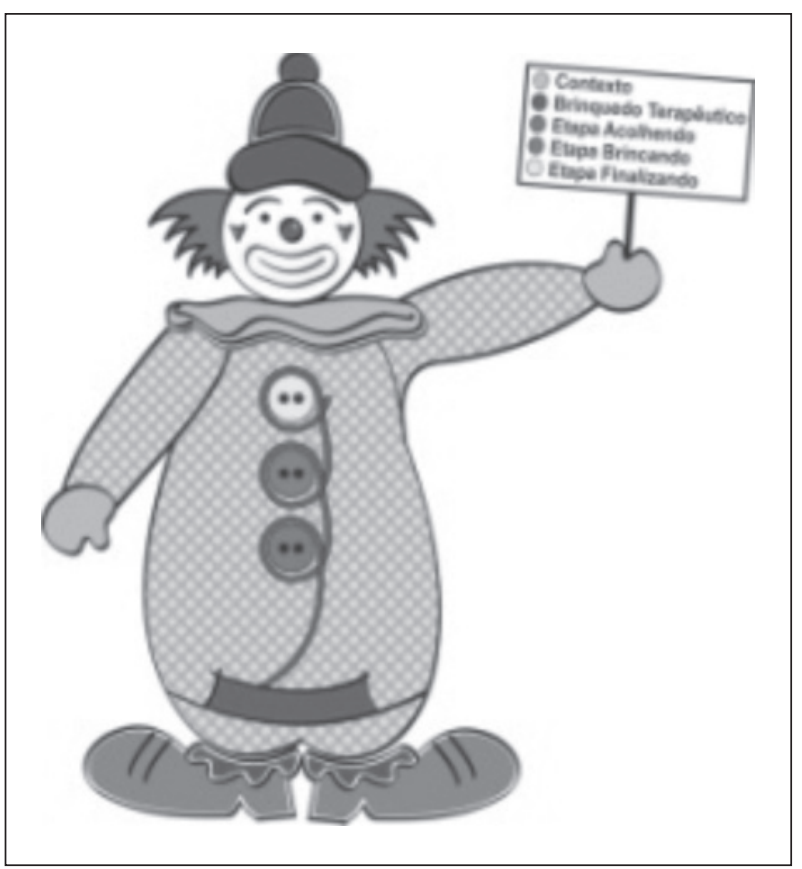

Figure 1 - Nursing Care Models for Children Victimized of Violence $^{14}$

The care model was applied together with four children, that suffered physical violence, and/ or sexual, and/or negligence, with ages between ten and twelve years, of which two were female and two masculine, in two homes, in the city of Florianópolis, Santa Catarina, Brazil. ${ }^{14}$

\section{THE METHODOLOGICAL WAY}

For the realization of the evaluation of the mode ${ }^{14}$ we used the proposed Instrument for the
Evaluation of the Nursing Care Models. ${ }^{13}$ This Instrument contained nine topics: Internal consistency criterion, Criterion of empirical adequacy frame of reference/ theoretical, Criterion of empirical adequacy methodology, Pragmatic analysis of the appropriateness criteria, Theoretical-practical criterion, Significance of the criterion, Methodological consistency criterion, Simplicity criterion and solvability criterion. Elaborated instrument and validity during the Doctorate thesis, realized in the Post-graduation Program of the Federal University of Santa Catarina, during the period of 2005 to 2008 , by a panel of specialists. To compose the panel of specialists thirty nine Brazilians specialists were selected, utilizing the higher score criteria of the curriculum registered in the lattes platform (higher than 100 points), using the following criteria of inclusion: be a nurse, Brazilian; publish work in the area of child, violence and methodology of study; posses a doctorate or post-doctorate and participated in study groups. After the acceptance the expert was sent to the proposal of the evaluation of the nursing care model instrument ${ }^{13}$, the model of care $^{14}$, a summary explanation about the purpose of the study and the authorization term. Out of the total of the specialists, eighteen responded, out of which four were of the south region, five of the south east, two from the north, six from the north east and one from the centralwest region of Brazil.

The analysis of the specialists reply was realized to covering all the different dimension in order to provide sustainability to the evaluation process, including the qualitative analysis of the reply objective and other qualitative analysis of the texts elaborated by the specialists as part of the evaluation process they made. It should be noted that the experts answered yes or no and some had only suggestions to the model.

The suggestions and review of the specialists were analyzed through the following steps: 1 - elaboration of a framework with texts of suggestions and review for the criteria of evaluation of the specialists; 2 - codification of the texts; 3 - grouping of similar codes; 4 - identification of the corresponding themes; 5 - realization of the interpretation of the specialists answers content.

The rigor and the ethic considerations of this study are interconnected through its development, because ethics is shown with the realization of adequate and reliable utilization of instruments and evaluative criteria in the proposed issues, while the accuracy shown by the fidelity to the main study. 


\section{RESULTS AND DISCUSSION}

The care model ${ }^{14}$ obtain the higher index of concordance of the specialists were the criteria of solvability (fifteen specialists) and of significant (fourteen specialists) of the model. For some criteria, the specialists did not respond to the alternatives (yes or no), they only pointed to suggestions, which were analyzed qualitatively.

The Internal consistency criterion focuses on the context and the content of the reference/ theoretical frame. This criteria require that the elements of the framework reference/theoretical, in other words, the concepts and presuppositions, are congruence with philosophical demand of Discipline(s), the model (s) conceptual (s), the theoretical, the scientific studies and surroundings. It possessed nine evaluative questions.

Of the total number of specialists, nine evaluate that the care mode ${ }^{14}$ have internal consistency, while two did not agree, and five of the specialists only presented suggestions or reviews, without indicating their agreement or disagreement.

With relation to suggestions presented, some specialists affirm that the philosophical vision of the study is evident in a clear form, as well as the object of the explicit. The mark reference elaborates a sustainable philosophical and theoretical model. The concepts and assumptions were considered suitable to the model and practice of care.

Moreover, important considerations were presented with the aim of improving the model. Further deliberations were suggested of the study object, and the need for further deepening of the theoretical frame of reference, using knowledge of related principles.

The Criterion of empirical adequacy frame of reference/theoretical refers to the foundation landmark of the scientific and theoretical/methodology or specific instruments that are developed to guide the practice through the care model. In this criterion three questions are considered.

Twelve of the specialists agree with the care model ${ }^{14}$ has empirical adequacy of reference landmark, one disagrees with this assertion and five of the specialists have only suggestions. Some of the specialists say that the demand of the philosophical frame of reference model is congruent with the empirical evidence and the proposed methodology. However, there are suggestions to clarify how it was accomplished with the congruence as a landmark with the empirical evidence, since to some specialists there is the need to describe in a more detailed reality of study.

The detailed study of the reality was described in review of the literature and methodology Masters ${ }^{14}$, which led to the proposed model. However, it was not sent in its entirety to the specialists, they were only sent a frame of reference and methodology. Thus, these suggestions take us back to reflections: first that the second reference point and the possibility of considering the need to include in the presentation of the model a general description of the concept that generates the proposition. We agree with the need to widen the frame of reference, but thinks it is not necessary to detail it in the general context. Since a model of the context of care should have a wide use and not specific only to a particular location and/or institution.

The Criterion of empirical adequacy methodology relates to the soundness of the methodology conducted by the congruence of the methodology with empirical evidence. In this criterion two questions are considered.

Eleven of the specialists, thinks that the model ${ }^{14}$ has empirical adequacy of the methodology, one disagrees with it, and six have made suggestions and comment in order to refine the model. The specialists suggested more detail of the reality studied, thus achieve greater connection between empirical evidence and methodology.

A pragmatic analysis of the appropriateness criteria and practice theoretical-assessment Instrument of models of care can be performed jointly, since both had the same suggestions.

The pragmatic appropriateness is determined by the revision of all descriptions of the use of it in practice. The model should be socially significant for driving results for those involved in actions, such as a decrease in complications, the favoring of actions, such as a decrease in complications, the encouragement of health conditions and increased in satisfaction with the care provided. In this criterion six issues are considered.

The Theoretical-practical criterion development of thinking during the implementation of a macro model for the understanding of the phenomenon, involves the frame of reference/ theoretical and practical. The model of care in providing macro-micro perspectives is leading us to move forward, and aiming at a solid construction. In this criterion three issues are considered.

For twelve of the specialists the care model ${ }^{14}$ proposal presents pragmatic appropriateness, and 
one disagrees with this assertion and five made comments or descriptive suggestions. While for eleven of the specialists, the model favors the development of theoretical-practical, and no one disagreed, but seven made suggestions and comments.

According to the specialists, the care model ${ }^{14}$ presented and provides significant support for the elaboration of care to children victimized of violence, thereby providing a humanized care, since it has all the steps involved in the process of care.

Besides this, they also report that this care model leads to favorable results not only for children, as well, to nurse and the health team. The specialists suggested that the same can also be applied in different sectors of the area of health, such as hospitals and programs like the Family Health Strategy/Brazilian Ministry of Health, for been easy to apply and can be a breakthrough when diagnosed the deficits of care that the child has. However, it needs to be improved, and to this end, the specialists suggested simplifying the methodology, to facilitate its application, with clarification to the steps to be taken by nurses through the details of the activities to be conducted in therapeutic toy sessions. The inclusion of family in the process was one of the issues cited by the specialists.

We agree with the specialists about the necessity of detailing the steps to be taken in the sessions of therapeutic toy. Notably, the steps may be described again and be more explicative, but we realize that there is no way we can pre-establish all actions of nursing. Actions are guided by the principles of care $^{17}$ and defined from the needs expressed by each child, since we are advocating in favor of care that considers the individuality of each child.

They also agreed that there was a gap in the care model $^{14}$ proposed, because the family was not incorporated in the process. We have to emphasize that these Children's Shelters for were away from the contact of their family because there was no family or measure of protection determined in court. However, the family may be incorporated into the process, when there is no model of restricting family from participating, as a possibility to establish and/or strengthen such linkages, provided there is agreement on the part of the child.

The significance of the criterion demonstrates the relevance of the model of care for society and for nursing. Besides showing the idea emerged from the study and the rationality for its development. In this criterion three questions are considered.

Fourteen of the specialists agree that the care mode $^{14}$ has proposed significant, though they disagree, two made suggestions and comments, mostly positive.

According to the specialists the model ${ }^{14}$ has significance, because it qualifies the practice of care, considered the proximity and depth in the inter-relation between the Nurse and child. From this action, it favors the systematization of the actions of care, that is, the actions to be undertaken by the nurse are established and prescribed from the real needs of the child.

For specialists, the care model ${ }^{14}$ has prospects for general use, because situations can change and describe the practice of caring for children victimized of violence, since it considers the weaknesses and the need for care and protection of children. Also notes that, in this case, the therapeutic toy and as a means to achieve the nursing diagnoses and defines its intervention.

According to one of the specialists, there is need to describe with more details the results of applying the model to practice.

The Methodological consistency criterion is aimed to ensure congruence between the macro reference/and theoretical methodology. In these criteria three questions are considered.

According to eleven of the specialists the mode ${ }^{14}$ has methodology coherence, two of the specialists did not agree, and five of the specialist had suggestions and descriptive comments. To some specialists the object of study is clear and well thought out methodology, however, for others, it needs some adjustment.

The specialist suggested the deepening of theoretical criterion frame of reference. However, the greatest number of suggestions concerning the methodology, because it is the objective of the evaluation of the criterion. Thus, they suggested the revising of the wording and clarify the content of the methodology standard, as well as, clarify the process step of the methodology through its detailed description and the simplification of their denominations, that is, changing the denomination steps: "welcoming" and "joking".

The specialist suggested clarifying and describing the actions of nurses in methodological steps. As the graphical representation, the specialists commented that it is a little bit confusing, and they suggested performing an algorithm. We agree with the specialists that the graphical representation of the model is not clear. The elaboration of algorithm can have a greater facility for understanding the model. 
The denomination of steps was chosen through the stages in order to stay on your goals, to facilitate the understanding of the nurse clearly was the focal point of each step. Therefore, the first is denominated as "welcoming" which has as purpose "the establishment of a relationship between the child and nurse, also because we assume that care needs to be done with interaction" ${ }^{14: 62}$ The second step is denominated the "playing" where it carries out most of the process, or where, the realization of the highest number of therapeutic sessions of therapeutic toy occurs in this stage. The third stage, denominated "conclusion", in(s) last again(s) session(s) to be developed with the children. Thus, changes in denomination of the steps do not seem pertinent.

The Simplicity criterion concerns the ability of the landmark reference/theoretical clearly explain the phenomenon interest, and the methodology path and methods used must be clearly described, and the model of care should be of easy understanding and applicability. In this criterion three issues were considered.

The Evaluation of the Care Model ${ }^{14}$ demonstrated that there is fragility about the Simplicity of it, because nine of the specialists agree, while two disagree there was a great number of suggestions, or to say, that seven of the responses of the specialists presents suggestions or comments.

The Solvability criterion for verifying if the model of care applied contributes to the modifications or not of the practice. In this criterion it recognizes the changes in the practical-Assistance or if the model favors the elaboration of the alternatives of solution to possible problems. In this criterion two questions were considered.

The Solvability criterion obtained a higher number of positive reply from the specialists, or to say, fifteen of the specialists agreed. Only one specialist disagrees and two of the specialist gave suggestions and comments.

According to the specialists the model offers subsidies to the resolution of the problems, because it permits the evaluation of the necessities of the child victim of violence, and intervene in a systemized form on the adverse situations, moreover promoting an adequate Nursing care and congruent the necessities of each child.

\section{FINAL CONSIDERATIONS}

The necessity of evaluating of the care model and the due relevance of same in the theoretical sustentation and methodology of the actions of nursing, that is, through a model of care, nursing can express its theoretical and practical domain.

From the evaluation of the care model ${ }^{14}$ proposed, we notice that the elaboration of the model of care to the practice and from such makes a difference in the systematization and construction of nursing knowledge. The Evaluation of the Care Model ${ }^{14}$, does not only serve for evaluation of this model, but we reported the definitions of propositions required to compile the models of care. From the suggestions and comments of the specialists, it is possible to perceive where a model of care needs to be strengthened to be so called and implemented in professional practice.

The greater difficulty found in the process of evaluation was during the analysis of responses from specialists, in view of the dissonance between the assessments of same.

Thus, the analysis was often difficult, but all the suggestions and comments were considered, that is, all responses were valued, in order to evaluate the relevance and appropriateness of the model.

We found out that the process of Evaluation of the Care Models is not simple, however, it is essential that they are evaluated, to promote the understanding of those who analyze them, and the willingness to keep the motion of implementation, evaluation and reformulation in a process that is not extinguished, but if perfected and meets the physical/material world, spiritual and sensible, which are presented in each action of nursing care.

As for the elaboration of the care model, also for its evaluation, abstraction is necessary, knowledge of literature and the practice. Moreover, this process must be clear and precise, and must cover the objectivity and subjectivity of the model, so that those who use it can understand and perceive it in full.

Finally, from the evaluation realized, the Care Model for Children Victimized of Violence ${ }^{14}$ can be considered a model of care for nursing, although it needs some adjustments, mainly in the framework of concept and clarification of methodology, besides its validation in practical application.

\section{REFERENCES}

1. Polit DF, Beck CT. Nursing research: generating and assessing evidence for nursing practice. $8^{\mathrm{a}} \mathrm{ed}$. Filaphelfia (US): Wolters Kluwer/Lippicott Willians \& Wilkins; 2008 
2. Fawcett J. Knowledge contemporary nursing knowledge: analysis and evolution of nursing models and theories. $2^{\mathrm{a}}$ ed. Philadelphia (US): F. A. Davis Company; 2005.

3. Meleis AI. Theoretical nursing development and progress. $3^{\text {a }}$ ed. Philadelphia (US): Lippincott; 1997.

4. Rocha PK, Prado ML. Modelo de cuidado ¿Qué es y como elaborarlo? Index de Enfermería. 2008 AbrJun; 17(2):128-32.

5. Erdmann AL. Diagnóstico de problemas num sistema de enfermagem de hospital de ensino: proposta de um modelo. Rio de Janeiro (RJ): UERJ; 1987.

6. Zanchetta MS. O processo de avaliação de um modelo assistencial em cancerologia: modelo assistencial. Rio de Janeiro (RJ): UERJ; 1990.

7. Carraro TE. Resgatando Florence Nightingale: a trajetória da enfermagem junto ao ser humano e sua família na prevenção de infecções [dissertação]. Florianópolis (SC): Universidade Federal de Santa Catarina, Programa de Pós-Graduação em Enfermagem; 1994.

8. Teixeira MA, Nitschke RG. Modelo de cuidar em enfermagem junto as mulheres-avós e sua família no cotidiano do processo de amamentação. Texto Contexto Enferm. 2008 Jan-Mar; 17(1):183-91.

9. Amezcua M, Toro AG. Los modos de análisis en investigación cualitativa en salud: perspectiva crítica y reflexiones en voz alta. Rev Esp Salud Pública. 2002 Sep-Oct; 76:423-36.

10. Morse JM. Insight, inference, evidence, and verification: creating a legitimate discipline. IJQM [online]. 2006 Mar [acesso 2008 Jun 10]; 5(1):. Disponível em: http://ejournals.library.ualberta. ca/index.php/IJQM/article/view/4412/3531

11. Morse JM, Barrett M, Mayan M, Olson K, Spiers J. Verification strategies for establishing reliability and validity in qualitative research. IJQM [online]. 2002 Sep [acesso 2008 Jun 10]; 1(2):. Disponível em: http:/ / ejournals.library.ualberta.ca/index.php/ IJQM/article/view/4603/3756

12. Cálderon C. Criterios de calidad en la Investigación Cualitativa en Salud (ICS): apuntes para un debate necesario. Rev Esp Salud Pública. 2002 Sep-Oct; 76:473-82.

13. Rocha PK. Construção e validação de um instrumento para avaliação de modelos de cuidado de enfermagem [tese]. Florianópolis (SC): Universidade Federal de Santa Catarina, Programa de Pós-Graduação em Enfermagem; 2008.

14. Rocha PK. Brinquedo terapêutico e crianças institucionalizadas vítimas de violência: propondo um modelo de cuidado de enfermagem [dissertação]. Florianópolis (SC): Universidade Federal de Santa Catarina, Programa de Pós-Graduação em Enfermagem; 2005.

15. Borba RIH. Mesa redonda: o brinquedo e a assistência de enfermagem à criança. Enferm Atual. 2002 Nov-Dez; 2(24):9-11.

16. Green CS. Entendendo as necessidades das crianças através do brinquedo terapêutico. São Paulo (SP): EEUFF; 1974.

17. Morse JM, Solberg SM, Neander WL, Bottorff JL, Johnson JL. Concepts of caring and caring as a concept. ANS. 1990 Sep; 13(1):1-14. 